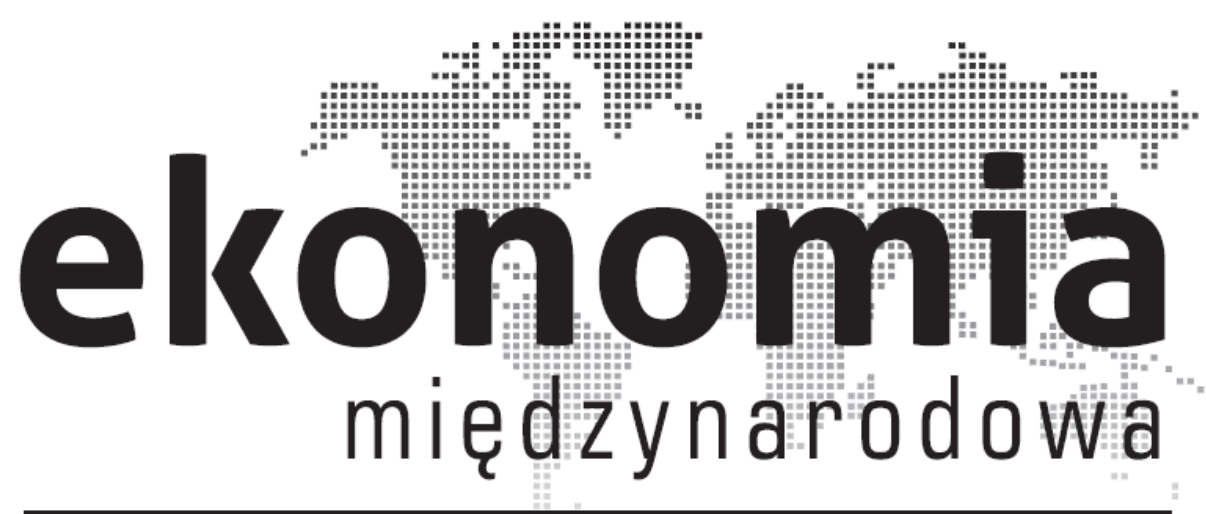

Ekonomia Międzynarodowa

$\mathrm{Nr} 13$ (2016)

Wydawca: Uniwersytet Łódzki

(Publisher: University of Lodz)

www.ekonomia-m.pl

ISSN: 2082-4440 - wydanie papierowe (paper edition)

ISSN: 2300-6005 - wydanie elektroniczne (electronic edition)

Wersja elektroniczna czasopisma jest wersją referencyjną

(Electronic edition is the reference version of the journal)
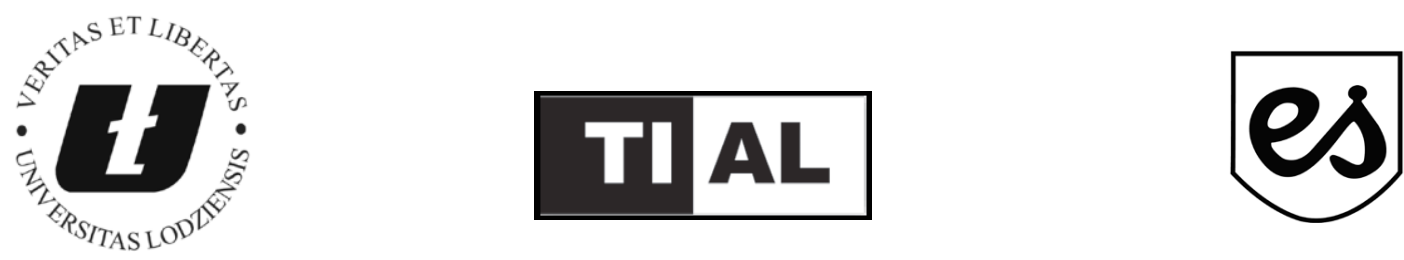


\section{A historical retrospective and the essence of strategic financial planning}

Olha Nestor*

\section{Introduction}

The environment of enterprises is currently undergoing radical and dynamic changes which are occurring much faster than in the past. This is due to the complexity of the system of relationships between all aspects of social life, quantitative and qualitative development of scientific and technological progress, and increased competition. These factors mean that the financial position of an enterprise in the future is determined by today's decisions. Strategic financial planning is especially important under these conditions. However, it is impossible to use something without knowing about its purpose. The goal of this paper is to study the essence of strategic financial planning, its historical retrospective and its importance for an enterprise's effective functioning.

The various aspects of strategic financial planning have been studied by many scientists, including Hofer and Schendei (1978), Brealey and Myers (2003), Shvaika (2003), Goncharov, Nepochatov and Pchelynska (2006), Davydenko (2007), Gerasymchuk and Vahovych (2007), Didenko (2008), Martsyn (2008), Ostrovska (2008), Ross, Westerfield and Jordan (2010), Brigham and Ehrhardt (2011), Bilyk (2012), Nepochatenko, Bechko, Huzar and Kolotukha (2012), Sytnyk (2012), Poddyerohin, Bilyk and Buryak (2013), Synchak and Krushynska (2013), Tkachenko (2013) and others. However, some aspects of strategic financial planning are still unclear. In particular, further research is needed to determine the essence of strategic financial planning, which will be done through reviewing its history as well as its main objectives and advantages.

\footnotetext{
* Olha Nestor-MSc, Department of Finance, Monetary Circulation and Credit, Faculty of Economics, Ivan Franko National University of Lviv.
} 


\section{Strategic financial planning: a historical review}

Enterprises are at the centre of the theory and practice of planning in emerging economies. Commercial enterprises were the first to understand the role of financial planning in ensuring effective economic activity and they began to use it in their practice in market economies. From the beginning, corporate planning was based on the genetic concept in market economies. In this concept, plans are based on studying market processes, patterns of development and market conditions, etc. This planning was short-term and was implemented in the form of budgeting and control. Short-term methods of financial planning were developed during this period.

The need for long-term planning arose under the influence of scientific and technological progress and the complications which arose due do different business organizational forms. The theoretical basis and practical tools for long-term planning, based on the concept of making plans in accordance with predictable future development trends, appeared and was expanded in the 1950s. At the stage of economic growth, this approach proved to be very effective.

In the early 1960s, the economic environment began to change rapidly. The reasons for these changes were insufficient stability of the external environment and increased competition. In such a situation it was necessary to revise the conceptual foundations of planning. Under these conditions, the theory and practice of planning were focused on the organic combination of genetic and teleological (target) approaches. The result of this combination was the targeting character of planning, which means that resources were seen as the means to achieve goals, and the plan was a set of possible alternatives regarding the predicted changes in the external environment. This approach is called "strategic planning". It was developed from the early 1960 s to the early 1970 s. The basic principle of strategic planning was: "from the future to the present". It is fundamentally different from the basic principle of long-term planning - "from the present to the future".

An important role in strategic planning is the analysis of the prospects of the company - the trends, threats and opportunities that could change the established trends. The idea that the future does not necessarily have to be better than the present dominated. This approach fully corresponded to the features of the economy of the period. In the mid-1970s, the unstable economic environment intensified and it resulted in the search for new management approaches. "Strategic management" is based on the concept of strategic planning and its theoretical principles and its practical tools remain relevant today. Planning is an integral part of strategic management, proved by the significant amount of attention it has drawn from specialists in strategic management planning.

It is important to understand what the word "strategic" means. The "strategy" concept borrowed from the lexicon of the Army. It means a plan of action in a particular situation, depending on the participants' response. The term then entered 
the lexicon of business management, thus we can see the concept of "strategic planning", "strategic management" and "strategic thinking."

Business strategy represents a generalized model of actions which are necessary to achieve goals by way of coordinating and distributing resources. The aim of the strategy is to achieve long-term competitive advantages that will ensure high profitability of the business in the future.

\section{Approaches to the definition of "strategic financial planning"}

Planning is the most difficult and the most important function of management. There are many types of planning: production, trade, investment, financial, social and others. But we will concentrate only on financial planning. Different kinds of financial planning are distinguished. This is due to the variety of parameters used for comparison, such as the time horizon, facilities, resources, etc. We believe that the most important parameter is the time horizon; it is the period on which the financial planning focuses. Because of this the following types of financial planning are marked out.

Figure 1. The structure of the financial planning system

Strategic financial planning
Tactical financial planning
Operational financial planning

Source: own elaboration.

These three types of financial planning are, at the same time, the levels of planning, and together they form a system of financial planning. They are closely linked, and therefore errors or inaccuracies made a tone of the levels may affect the other two. So we can conclude that the correctness of strategic financial planning affects the accuracy of tactical and operational planning.

However, not all scientists agree on the three-level structure of the system of financial planning. For example, Gerasymchuk and Vahovych (2007) allocate another two elements in this system, such as financial forecasting and budgeting. We believe that a scheme with five tiers of financial planning is not correct. Financial forecasting and budgeting help to get the information needed for decision-making, however, we consider it inappropriate to allocate them separate levels.

When it comes to similarities between financial planning and financial forecasting, the unity of purpose and objectives should be mentioned. Prediction provides the basis for making planned decisions and generates variants of possible directions of management. Concerning the differences, they are due to the time 
factor and the level of uncertainty, because forecasting is a research base for planning through proactive forecasts. In addition, forecasting results in establishing a few possible variants of the future, while planning is a unique solution, even if it is based on one of the variants.

As for budgeting, it is an effective tool for improving the efficiency of business management, significantly improving performance. As a rule, budgeting covers a period of one year and is a means of monitoring the effectiveness of management decisions in finance. It means compiling a planning document that reflects the income and expenditures of the company's business operations and the results related to their implementation. In countries with a developed market economy, a budget is a quantitative plan of particular indicators such as financial, economic or natural ones that show the company policy.

It is necessary to clarify the essence of the concept of "strategic financial planning". In the scientific literature, the following synonyms of this concept often occur: "long-term financial planning" and "perspective financial planning", but there is no clear distinction between the two. Among the authors there is still no single approach to the definition of the essence of strategic financial planning. Most American and European scientists identified the definition of "long-term financial planning" and "strategic financial planning". In particular, Ross, Westerfield and Jordan(2010)describe long-term financial planning. We believe that such identification is not correct because of a change of the planning concept-from "long-term" to "strategic" planning. The difference between these concepts is the existence of a clear strategy (in strategic planning) and setting goals to help implement this strategy. Long-term planning helps to achieve goals and solve certain problems arising during this process, however, it does not provide the development and implementation of the strategy.

Strategic financial planning is an important part of the planning of an enterprise. During its implementation, the key financial targets of existing business are identified, or clear guidelines for the newly created business are outlined. These objectives must be consistent with each other in time and resources. Strategic financial planning specifies the financial strategy of an enterprise and contributes to the achievement of its objectives. In addition, strategic financial planning has the longest time horizon among all levels of the system - more than 5 years, normally 5-10 years, while multinationals may set a time horizon of a decade or even several decades. Long-term financial planning is different from strategic planning due to its time horizon $-2-5$ years. However, its main difference, in our opinion, is its purpose - to solve specific problems of the financial strategy of the enterprise. Financial planning is also called perspective planning, the word 'perspective' meaning "which involves following the development of something; designed for many years in the future". Therefore, we see that strategic financial planning can be called long-term or perspective planning, but note very long-term or perspective financial plan can be called strategic. Thus, we can conclude that strategic financial planning is the process of 
identifying the key financial objectives of an entity and developing a plan to achieve them within the financial strategy. Therefore, we believe that the terms "strategic financial planning", "long-term financial planning" and "perspective financial planning" differ and their identification is incorrect. They need to be divided.

But there is another point of view. For example, Ehrhardt and Brigham(2011) believe that most companies have strategic plans, operating plans, and financial plans. Their point of view on the planning system is in Figure 2.

Figure 2. The planning system by Ehrhardt and Brigham

Strategic plans

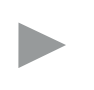

Financial plans

Source: own elaborations based on Brigham, Ehrhardt 2011.

Strategic plans usually have mission statements, a corporate scope, corporate objectives, and strategies. The strategic plan provides a "vision" of what the firm's top management expects, and without such a vision, the firm is not likely to be successful. Operating plans provide detailed implementation guidance to help the firm realize its strategic vision. And financial plans help to manage the corporate financial resources in a rational way.

Thus, we can see that strategic and financial planning are different there, so we don't see strategic, tactical and operational financial plans. We believe that financial planning must be linked to the overall strategy of the entity and facilitates its implementation through the development and implementation of financial strategies. It is therefore advisable to distinguish strategic financial planning in the financial planning system.

Strategic financial planning as a management tool has advantages and disadvantages (Figure 3).

Figure 3. Advantages and disadvantages of strategic financial planning

\section{Advantages}

- High level of probability of the planned scenarios.

- Effectiveness of formal forecasting of future challenges and opportunities of the enterprise in the market economy.

- Provides a basis for rational decision-making.

- Promotes reducing risk in decision-making.

- Provides integration of goals and objectives of all structural units and performers of enterprises.

- Helps to reduce risk in decision-making..

- Promotes efficient use of resources in the enterprise.

\section{Disadvantages}

- It doesn't provide a detailed description of the future picture for the enterprise, giving only a qualitative description of the state to be reached by the enterprise.

- There is no clear algorithm to draw up and implement the plan.

- The negative effects of mistakes are quite serious.

- Specific tools of strategic financial planning depend on specialist skills, professional experience and intuition.

- Requires a lot of time and resources.

Source: own elaborations based on Martsyn 2008; Ostrovska 2008; Shvaika 2003. 
The set of problems that strategic financial planning solves defines its essence. As strategic financial planning is one of the levels of financial planning, it is logical to accept that it performs the same tasks as the system of financial planning in general. The main objectives of strategic financial planning include:

1. defining the methods of effective investment and assessing its rational use;

2. enforcing are a balance between planned revenues and expenses, providing solvency and financial stability.

3. managing companies' cash flows;

4. providing the necessary financial resources for current operating, investing and financing activities;

5. the distribution of income concerning the interests of the company, share holders and other investors;

6. establishing sustainable financial relationships with other entities, such as other companies, banks, investment funds and insurance companies;

7. analysing the availability of the budget or state funds and possible contacts with banks and other creditors;

8. identifying reserves and the mobilization of all resources for profit growth from ordinary activities and any increase in other income;

9. monitoring the financial condition, solvency and credit worthiness of an enterprise;

10. analysing the relationships between possible decisions about dividends, financing and investment;

11. predicting future consequences of decisions to avoid unexpected situations and for a clearer understanding of the relationship of current and future solutions;

12. efficiently using income and other financial resources;

13. controlling the whole enterprise and the centres of financial responsibility;

14. implementing the objectives developed in the form of specific financial indicators;

15. assessing the availability of funding laid down in the production plan of the economic development (Nepochatenko et al. 2012; Poddyerohin et al. 2013; Tkachenko 2013).

\section{Conclusion}

We can draw the following conclusions: strategic financial planning is an important part of the concept of the strategic management of an enterprise. It allows for the identification of the key financial objectives of the transactor and the development of a plan to achieve them within the financial strategy. However, inspite of this, among scientists there is still no single approach to the definition and the essence of the concept. 
The review of the historical retrospective of strategic financial planning shows that the development of strategic financial planning was based on a study of market processes, patterns of development and market conditions. It allowed businesses to take into account the dynamics of the market economy for effective planning of the transactor's activities. With the development of the theory of strategic planning, its concept changed - the objectives and expected future financial positions were defined, and planning was carried out to achieve these targets. This concept differs from the concept of long-term planning which had dominated before. It is possible to change the view of planning and its potential as a tool for enterprise management on the market.

The essence of strategic financial planning is revealed through the tasks that it solves. However, it should be noted that strategic financial planning as a management tool has both advantages and disadvantages. It is necessary to note that errors and short comings made when using it can have serious negative consequences.

\section{References}

Bilodid I.C. (1970-1980), Slovnyk ukrains'koi movy v 11 tomah, Naukova dumka, Kyiv.

Bilyk M.D. (2012), Finansovi aspekty innovatsiyno-investytsiynogo rozvytku pidpryemstv, Kyiv: TOV PanTot.

Brealey R.A., Myers S.C. (2003), The Principles of Corporate Finance-Seventh Edition, The McGraw-Hill Companies.

Brigham E.F., Ehrhardt M.C. (2011), Financial Management: Theory and Practice, Thirteen Edition, South-Western Cengage Learning.

Davydenko N. (2007), Finansovyi menedzhment, TOV Vydavnytstvo "Aspect", Nizhin.

Didenko V.M. (2008), Menedzhment, Condor, Kyiv.

Gerasymchuk Z.V., Vahovych I.M. (2007), Finansovyi menedzhment, Nadstyr'ya, Luts'k.

Goncharov V.M., Nepochatov S.I., Pchelynska V.A. (2006), Finansy pidpryemstv, TOV "Almateo", Donetsk.

Hofer C., Schendei D. (1978), Strategy Formulation: Analytical Concepts, St. Paul: West Publishing.

Martsyn V.S. (2008), Planuvannya yak osnovna skladova protsesu finansovoi diyal'nosti, "Finansy Ukrainy", No. 4 (149)/2008.

Nepochatenko A.A., Bechko P.K., Huzar B.S., Kolotukha S.M. (2012), Finansovyi menedzhment, Vydavets "Sochinskyi", Uman.

Ostrovska G. I. (2008), Finansovyi menedzhment, Pidruchnyky i posibnyky, Ternopil.

Poddyerohin A.M., Bilyk M. D., Buryak L. D. and others (2013), Finansy pidpryemstv, KNEU, Kyiv. 
Ross S.A., Westerfield R.W., Jordan B.D. (2010), Fundamentals of corporate finance - 9th ed., Alternate ed., The McGraw-Hill/Irwin.

Shvaika L.A. (2003), Planuvannya diyal'nosti pidpryemstv, "NovyiSvit-2000", Lviv. Synchak V. P., Krushynska A. V. (2013), Finansovyi menedzhment, Khmelnytsky University of Management and Law, Khmelnytsky.

Sytnyk H. (2012), Genezys i suchasna paradygma finansovogo planuvannya, “Aktual'ni problemy ekonomiky", No. 7(133).

Tkachenko I.P. (2013), Finansovyi menedzhment, DSTU, Dniprodzerzhynsk.

\section{Summary}

The author has reviewed the historical retrospective of strategic financial planning, distinguished the concepts of "strategic financial planning", "long-term financial planning" and "perspective financial planning" and determined that their use as synonyms is incorrect. The correctness of three-tier financial planning has been justified. The difference between financial planning, financial forecasting and budgeting has been explained. The problem of strategic financial planning, its advantages and disadvantages, has been considered.

Keywords: strategic financial planning, management tools, historical retrospective

\section{Streszczenie}

\section{Historia oraz istota strategicznego planowania finansowego}

W pracy rozważono historyczny kontekst wprowadzania i wykorzystywania pojęcia strategicznego planowania finansowego. Zestawiono je z pojęciami długoterminowego planowania finansowego oraz perspektywicznego planowania finansowego, wykazując, że synonimiczne stosowanie tych określeń nie jest uprawnione. Przytoczono także argumenty przemawiające za trójwarstwowym ujęciem planowania finansowego $\mathrm{w}$ podmiotach gospodarczych. Wyjaśniono różnice między planowaniem finansowym, prognozowaniem finansowym a budżetowaniem. Na zakończenie rozważono zalety i wady strategicznego planowania finansowego.

Słowa kluczowe: strategiczne planowanie finansowe, historyczna retrospektywa, instrumenty zarządzania

JEL: B26, G32, O16 